\title{
PENERAPAN MODEL PEMEBLAJARAN CREATIVE PROBLEM SOLVING UNTUK MENINGKATKAN LITERASI SAINS DAN MOTIVASI SISWA
}

\author{
Felisitas Dayanti1, Chandra Sundaygara2,Kurriawan Budi Pratama3 \\ Pendidikan Fisika Universitas Kanjuruhan Malang ${ }^{1,2,3}$ \\ E-mail : felidayanti98@mail.com
}

\begin{abstract}
Abstrak. Penelitian ini adalah bertujuan untuk mengetahui sejauh mana model pembelajaran Creative Problem Solving untuk meningkatkan literasi sains dan motivasi belajar siswa kelas VIII-A SMP PGRI 6 Malang. Creative Problem Solving (CPS) adalah pembelajaran yang berpusat pada pemecahan masalah yang diikuti dengan penguatan kreativitas. Model Pembelajaran Creative Problem Solving dapat menciptakan pembelajaran yang dapat merangsang siswa menyelesaikannya secara kreatif sehingga dapat digunakan dalam kehidupan sehari-hari. Subjek penelitian siswa kelas VIII-A SMP PGRI 6 Malang yang berjumlah 25 siswa. penelitian ini dilakukan dua siklus. Jenis penelitian ini PTK (Classroom Action Research) Prosedur pengumpulan data melalui observasi dan tes. Hasil penelitian keterlasanaan pembelajaran pada siklus I adalah $70,2 \%$ berada pada kualifikasi cukup biak dan pada siklus II 87,19 berada pada kualifikasi baik, sedangkan literasi sains pada siklus I rata-rata kemampuan siswa 75,17 dan pada sisklus II rata-rata kelas 80,08 dan motivasi belajar siswa pada siklus I $60.42 \%$ dan pada siklus II 86,12\% . Berdasarkan penelitian ini dapat disimpulkan bahwa model pembelajaran Creative Problem Solving dapat meningkatkan literasi sains dan motivasi belajar siswa.
\end{abstract}

Kata Kunci: Creative Problem Solving, Literasi Sains, Motivasi Belajar Siswa

\section{PENDAHULUAN}

Tujuan pembelajaran fisika yang terdapat di dalam kerangka Kurikulum 2013 adalah menguasai konsep dan prinsip serta mempunyai keterampilan mengembangkan pengetahuan dan sikap percaya diri sebagai bekal dalam melanjutkan pendidikan ke jenjang yang lebih tinggi serta mengembangkan ilmu pengetahuan dan teknologi (Kemdikbud, 2014). Berdasarkan tujuan pembelajaran tersebut maka penyelenggaraan mata pelajaran fisika di tingkat SMP/MTS menjadi wahana atau sarana untuk melatih para siswa supaya dapat menguasai pengetahuan, konsep, dan prinsip fisika. Untuk menguasai pengetahuan dan konsep, siswa harus memiliki literasi sains. Literasi sains adalah kemampuan menggunakan pengetahuan sains untuk mengidentifikasikan pertanyaan,memperoleh solusi dari sebuah masalah.

Berdasarkan hasil observasi di SMP PGRI 6 Malang kelas VIII-A permasalahan yang ditemukan adalah siswa kurang memahami materi yang dijelaskan. Siswa cendrung merasa malas jika mengikuti pelajaran fisika, dari 25 siswa hanya 10 orang siswa yang mendapatkan nilai diatas rata - rata atau mencapai KKM. Siswa yang mencapai KKM ada 10 siswa dan 15 siswa yang mendapat nilai dibawah rata-rata dan untuk motivasi pada pembelajaran IPA di SMP PGRI 6 Malang sangat rendah. Rendahnya motivasi dilihat dari keadaan siswa saat pelajaran fisika berlangsung bahwa siswa tidak bisa tekun dalam menghadapi tugas yang diberikan oleh guru misalnya siswa tidur di kelas dan bermain sibuk sendiri pada saat pembelajaran berlangsung, apalagi ketika tugas dianggap sulit oleh siswa.

Peran literasi sains dalam pembelajaran adalah untuk meningkatkan kompetensi peserta didik untuk dapat memenuhi kebutuhan dalam berbagai situasi termasuk dalam menghadapi berbagai tantangan hidup di era global, dengan literasi sains peserta didik akan mampu belajar lebih lanjut dan hidup di masyarakat moderen yang saat ini banyak dipengaruhi perkembangan 
sains dan teknologi (Toharudin,et.al, 2011). Literasi sains dapat mengembangkan kemampuan peserta didik dalam memahami prinsip-prinsip serta proses mendasar gejala sains dalam kehidupan sehari-hari (Hartati \& Asyari, 2015).Untuk memaham tentang literasi sains maka siswa harus memiliki motivasi. motivasi belajar yang dimiliki siswa berbeda-beda, ada siswa yang memiliki motivasi dari dalam dirinya sehingga kemauan belajarnya lebih kuat. Tetapi ada siswa yang motivasi belajarnya siswa yang dipengaruhi oleh lingkungan dan dorongan dari orang sekitar. Sistem pembelajaran akan tercapai apabila peserta didik memiliki dorongan untuk belajar (Aini, 2016).

Rendahnya motivasi siswa dalam pembelajaran fisika mengakibatkan prestasi belajar menurun (Kriswahyudi, 2009). Memberikan motivasi kepada seorang siswa berarti menggerakan siswa untuk melakukan sesuatu atau ingin melakukan sesuatu. (Sadirman. 2010). Oleh karena itu penting menciptakan suasana belajar yang mampu menumbuhkan motivasi dan ingin terus belajar. Untuk mengatasi permasalahan yang dihadapi siswa SMP PGRI 6 Malang pada pembelajaran IPA, perlu adanya perubahan pada proses pembelajaran. Guru perlu memilih model pembelajaran yang tepat untuk menarik perhatian siswa agar siswa bersemangat dalam mengikuti pembelajaran IPA. Sehingga dapat meningkatkan motivasi belajar dan kemampuan pemecahan masalah IPA siswa. Salah satu model pembelajaran yang diharapkan dapat meningkatkan motivasi belajar dan kemampuan pemecahan masalah IPA siswa adalah model Creative Problem Solving.

Motivasi belajar siswa dapat ditingkatkan melalui penerapan berbagai model pembelajaran inovatif, diantaranya adalah model pengajaran langsung melalui metode problem solving. Rustini (2008), pengajaran langsung dengan metode problem solving merupakan salah satu solusi untuk meningkatkan motivasi dan hasil belajar siswa.

Model CPS dapat menuntun siswa menemukan aktualisasi diri dimana guru memberikan pertanyaan di awal untuk menggali daya kritis siswa kemudian diarahkan siswa untuk berdiskusi dalam kelompok masing-masing. Dalam hal ini guru hanya sebagai moderator dimana hanya mengarahkan siswa pada topik materi atau masalah lalu siswa menemukan sendiri solusi dari masalah yang mereka hadapi dan guru hanya memantau proses belajarmengajar. Model pembelajaran CPS melatih peserta didik untuk memecahkan masalah dan membuat peserta didik aktif dan mengembangkan cara berpikir.

\section{METODE PENELITIAN}

Jenis penelitian yang digunakan peneliti dalam penelitian ini adalah Penelitian Tindakan Kelas (PTK). Setiap siklus terdiri dari perencanaan, pelaksanaan, observasi, dan refleksi. Teknik pengumpulan data yang digunakan adalah wawancara, observasi dan tes. Tes dilakukan untuk mengetahui kemampuan literasi sains peserta didik pada pokok bahasan tekakan hidrostatis dan hukum archimedes melalui tes berupa esai. Untuk motivasi melalui angket.

Subyek penelitian ini adalah peserta didik kelas VIII A SMP PGRI 6 Malang yang berjumlah dari 25 siswa.Variable yang diteliti pada penelitian ini adalah variabel bebas dan terikat, varibel bebas model pembelajaran Creative problem Solving sedangkan terikat literasi sains dan motivasi belajar.

Adapun instrumen yang dipakai adalah (1) lembar Observasi, yaitu: Keterlaksanaan proses pembelajaran sesuai dengan RPP, Skenario pembelajaran, dengan menggunakan pedoman penilaian pelaksanaan pembelajaran, Motivasi belajar siswa dengan berpedoman pada indikator motivasi belajar.(2) Perangkat Pembelajaran Pada kegiatan ini disusun perangkat pembelajaran berdasarkan kurikulum 2013 Yaitu : Rencana pelaksanaan pembelajaran (RPP), skenario keterlaksanaan pembelajaran digunakan sebagai alur pelaksanaan belajar mengajar, lembar kerja siswa (LDPD) digunakan sebagai pedoman dalam belajar kelompok siswa. (3) Perangkat Tes, untuk mengukur kemampuan literasi sains, yang diberikan pada siswa berjumlah 15 butir berbentuk esai. 


\section{HASIL DAN PEMBAHASAN}

Keterlaksanaan pembelajaran

Pelaksanaan kegiatan pembelajaran dengan menerapkan model pembelajaran Creative Problem Solving (CPS) secara keseluruhan dapat meningkatkan literasi sains dan motivasi siswa. Guru dalam penelitian ini berusaha menerapkan model pembelajaran CPS, sehingga mengalami peningkatan dari siklus I ke siklus II. Literasi sains siswa diperoleh dari hasil tes pada akhir siklus I di akhir pembelajaran, hasil tes tersebut sebagai acuan untuk mengukur peningkatan literasi sains dari siswa setelah dilakukan tindakan siklus I. Tes diberikan ini mencakup aspek pengetahuan dan aspek kompetensi sains siswa dengan jumlah soal 15 dari 25 siswa untuk mengetahui pemahaman siswa dari setiap aspek. Rata-rata literasi sains untuk silkus I 75,2. Dari 25 siswa hanya 15 siswa yang tuntas dan mencapai KKM.

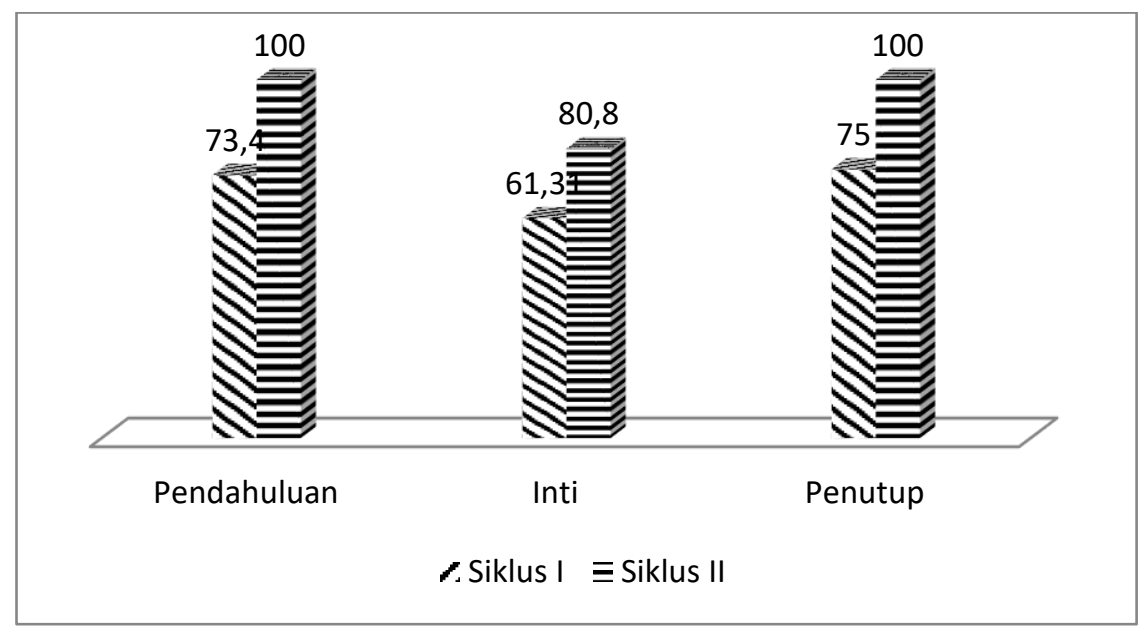

Gambar 1.1 keterlaksanaan pembelajaran siklus I dan II

Keterlaksanaan pembelajaran pada siklus I mencapai rata-rata presentase 70,2\% sedangkan rata-rata persentase pada siklus II sebesar 87,19\%. Pada siklus I keterlaksanaan pembelajaran cukup baik tetapi guru belum sepenuhnya bisa memberika materi kepada siswa secara terperinci, guru kurang mengaitakan materi yang dipelajari dengan kehidupan sekitar siswa, guru kurang memberika waktu untuk siswa dalam melakukan diskusi untuk memperoleh jawabaan dari masalah yang dibahas. Sedangkan pada siklus II guru menjelaskan materi secara terperinci, mengaitkan materi dengan lingkungan siswa, memberika kesempatan kepada siswa untuk memecahkan masalah dan memberika arahan dalam meyelesaikan maslah. Sehingga keterlaksanaan pembelajaran mengalami peningkatan di karenakan adanya perbaikan pada siklus I.

\section{Creative Problem Solving terhadap Literasi Sains}

Pembelajaran creative Problem solving merupakan salah satu model pembelajaran yang melakukan pemusatan pada pembelajaran dan keterampilan memecahkan masalah, yang diikuti dengan penguatan keterampilan (Hamzah, 2011). Guru dalam penelitian ini berusaha untuk meningkatkan motivasi dan literasi peserta didik dengan menggunakan model pembelajaran CPS, sehingga terbukti jika motivasi dan literasi sains peserta didik mengalami peningkatan jika dibandingkan dengan keadaan awal dan mengalami peningkatan dari siklus I ke siklus II. CPS adalah metode pembelajaran yang digunakan untuk menangani persoalan secara kreatif (Huda, 2014) dapat disimpulkan bahwa pembelajaran CPS ialah pembelajaran yang berpusat pada keterampilan pemecahan masalah yang dilakukan oleh siswa. 


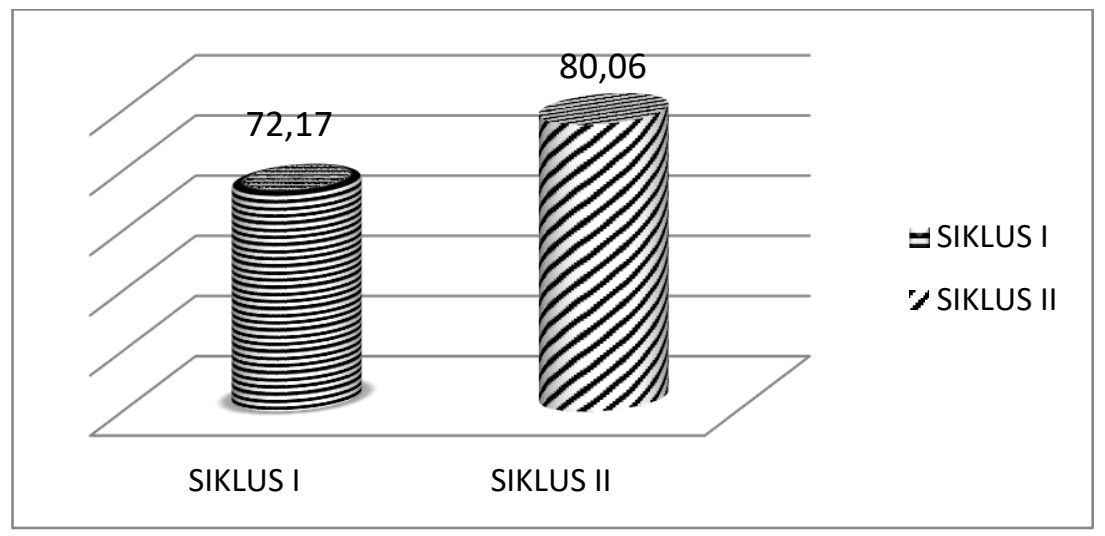

Gambar 1.2 Data Nilai Literasi Sains Siklus I dan Siklus II

Pada siklus I nilai rata-rata literasi sains 72,17 cukup rendah, rendahya literasi sains dikarenakan peserta didik kurang mengerti dengan pelajaran yang telah dijelaskan oleh guru, siswa tidak mencatat saat guru menjelakan materi, tidak ada keberanian untuk bertanya ketika belum paham. Pada siklus II literasi sais siswa mengalami peningkatan dengan rata-rata 80,06, perubahan tersebut dikarenakan ada perbaik disiklusi I yaitu siswa mencatat pada saat guru menjelaskan, bertanya kepada guru jika belum paham, guru menjelaskan kembali jika siswa belum paham, melatih siswa untuk mengerjakan soal. Pada siklus I nilai ketuntasan belajar $60 \%$ atau hanya 15 siswa dari 25 siswa, hal ini dikarenakan siswa ada yang tidak mengerjakan soal, mengerjakan soal tetapi tidak benar dan jawabanya tidak sesuai dengan soal yang ada. Namun pada siklus II nilai ketuntasan belajar $80 \%$ ini dikarenakan ada perbaikan disiklus I siswa mengerjakan semua esai serta menjawab berdasarkan materi yang telah dijelaskan.

Meningkatnya literasi sains pada siswa karena siswa menguasai materi yang diberikan guru, adanya niat siswa untuk belajar dan mengerjakan tugas yang diberikan guru. peserta didik menggali fakta-fakta yang lebih banyak mengenai materi yang dipelajari. Antusias peserta didik dalam menyampikan siswa untuk memberikan solusi kreatif sebagai upaya pemecahan masalah yang dilakukan melakui sikap pola pikir kreatif siswa, memiliki banyak alternatif pemecahan masalah, memiliki ide baru dalam pemecahan masalah, terbuka dalam perbaikan, menumbuhkan rasa percaya diri, berani menyampaikan pendapat dan fleksibel dalam upaya pemecahan masalah (Sujarwo, 2006).

Kelebihan cerative problem solving sehingga mampu meningkatkan literasi sains peserta didik yaitu peserta didik diberikan kesempatan untuk memahami konsep-konsep dengan cara penyelesaian sebuah masalah, membuat siswa aktif dalam pembelajaran, mengembangkan kemampuan berpikir siswa karena disajikan masalah pada awal pembelajaran dan memberi leluasaan kepada siswa untuk mencari arah-arah penyelesaian, membuat siswa dapat menerapkan pengetahuan yang sudah dimiliki kedalam situasi baru. Berdasarkan paparan diatas dapat disimpulkan kelebihan dari CPS yaitu siswa siswa lebih aktid dalam pemeblajaran karena siswa yang mencari tahu sendiri pengetahuanya berdasarkan pengalaman yang dijumpai, melatih siswa untuk berpikir kretaif dan kritis dalam pemecahan masalah ( Huda, 2014)

\section{Daya Serap Siswa Aspek Kognitif}

Pada siklus I nilai rata-rata secara umum yang diperoleh siswa untuk literasi sains sebesar 72,17 dan nilai ketuntasannya $60 \%$ atau 25 siswa hanya 15 siswa yang mencapai KKM dan untuk siklu II rata-rata secara umum untuk literasi mencapai 80,06 dan nilai ketuntasan $80 \%$ atau 25 siswa yang memenuhi KKM 20 siswa, nilai terendah pada siklus yaitu 50 dan nilai tertinggi 85. Daya serap siswa untuk aspek kognitf pada C1 80\%, C2 64\%. C3 60\% dan C4 $48 \%$, jadi nilai rata-rata untuk aspek kognitf pada siklus I 6,30. Pada siklus I daya serap siswa masih rendah dari siklus II hal ini dikarenakan guru kurang menjelaskan secara terperinci materi yang dipelajari, siswa tidak memiliki keberanian untuk bertanya kepada guru jika belum memahami materi, kurang memberikan contoh soal pada saat pembelajaran, siswa tidak terbiasa mengerjakan soal yang berkaitan dengan pemecahan masalah. Sedangkan pada siklus II daya serap siswa meningkat dikarenakan guru menjelaskan materi secara terperinci, memberikan 
kesempatan kepada siswa yang belum paham untuk bertanya, memberikan contoh soal yang banyak dan membuat siswa memahami soal yang diberikan, melatih siswa untuk memecahkan sebuah masalah yang berkaitan dengan kehidupan siswa.

\section{Daya Serap Siswa Aspek Kompetensi}

Secaraa umum rata-rata literasi sains pada siklus I 72,17 dengan nilai ketuntasan $60 \%$ dan pada siklus II 80,06 dengan niali ketuntasan 80\%. Daya serap siswa untuk aspek kompetensi pada siklus I masih rendah sebesar $40 \%$, hal ini dikerenakan pada siklus I guru kurang memberikan motivasi kepada siswa untuk mendengarkan penjelasan guru pada saat pembelajaran, siswa kurang paham dalam menyimpulkan sebuah masalah, guru kurang menjelaskan masalah secara detail sehingga siswa ragu untuk mengungkapkan pendapatnya. Sedangkan pada siklus II mengalami peningkatan karena guru menjelaskan masalah sejelaskan mungkin sehingga siswa memahmai, memberikan motivasi kepada siswa untuk memperhatikan penejelasan dari guru, memberikan contoh bagaimna menyimpulkan sebuah masalah dan solusi untuk memecahkan masalah tersebut. Rata-rata aspek kompetensi pada siklus I 4,80 dengan kategori masih rendah, dengan adanya perbaikan pada siklus II maka pada siklus II rata-rata yang diperoleh sebesar 7,60. Sehingga dapat disimpulkan bahwa ada penigkat pada serap siswa pada aspek kompetensi. Daya serap merupakan kemampuan seseorang untuk menyerap atau menguasai materi yang dipelajari sesuai dengan mata pelajaran yang diajarkan dan daya serap merupakan tolak ukur untuk mengetahui sejauh mana pemahaman peserta didik mengenai mata pelajaran yang telah dipelajari (uno, 2014)

\section{Berdasarkan Ketuntansan Belajar}

Pada siklus I rata-rata yang diperoleh dari 25 siswa mencapai 72,17 dan hanya 15 siswa yang memenuhi KKM, dan untuk ketuntasan literasi sains pada siklus 1 mencapai $60 \%$. Pada siklus I ketuntasan belajar masih rendah dari siklus II hal ini dikarenakan siswa kurang memahami penjelasan dari guru, siswa kurang memahami soal yang dikerjakan, tidak mencatat penjelasan guru sehingga siswa tidak ada panduan untuk belajar kembali mengenai materi yang dijelaskan, kurang motivasi supaya siswa selalu bertanya jika belum apahm dengan materi yang dijelaskan. Sedangkan pada siklus II mengalami peningkatan untuk literasi sains, untuk niali rata-rata pada siklus II 80,06 dan ketuntasan mencapai $80 \%$ hal ini dikarenakan ada perbaikan pada siklus I yaitu guru menjelaskan kembali materi jika siswa belum paham, meminta siswa untuk mencatat suapay bisa belajar kembali materi yang telag dijelaskan, sebelum siswa mengerjakan soal guru menjelaskan masalah ada akan dikerjakan supaya siswa memiliki gambaran dalam menyelesaikan masalah tersebut sehingga pada siklus II ketuntasan belajar terdapat peningkatan. Guru yang menerapkan model Pembelajaran CPS mampu mendorong siswa menyelesikan permasalahan-permasalahan yang diberikan dengan cara yang kreatif dan menarik perhatian, sehingga dapat meningkatkan keinginan dan kesenangan siswa untuk mempelajari materi yang diberikan. Selain itu belajar dengan CPS menjadikan siswa lebih bermotivasi untuk belajar, menigkatnya keterampilan dan pengetahuan siswa serta kemampuan berpikir kreatif dapat mengangkat keinginan ini dapat menyebabkan terjadinya peningkatan hasil belajar siswa (Kandemir, 2007)

\section{Creative Problem Solving terhadap Motivasi Belajar Siswa}

Motivasi siswa yang mempengaruhi belajar siswa dapat dilihat dari tingkah laku siswa, seperti siswa menjadi lebih aktif dalam pembelajaran dan siswa berpartisipasi penuh dalam kegiatan pembelajaran yang sedang berlangsung. Motivasi juga dapat menentukan arah belajar siswa sebab ada tujuan dari kegiatan pelajaran itu sendiri. Sehingga motivasi dapat menimbulkan gairah, minat dan semangat siswa dalam belajar. Motivasi belajar yang muncul dalam diri seseorang dapat disebabkan oleh faktor intrinsikdan ekstrinsik. Kedua faktor tersebut disebabkan oleh adanya rangsangan tertentu. Sehingga dapat menimbulkan keaktifan siswa dan siswa belajar dengan semangat. Sehingga dapat disimpulkan bahwa model pembelajaran cerative problem solving dapat mempengaruhi motivasi belajar siswa (Sudriman, 2011). 


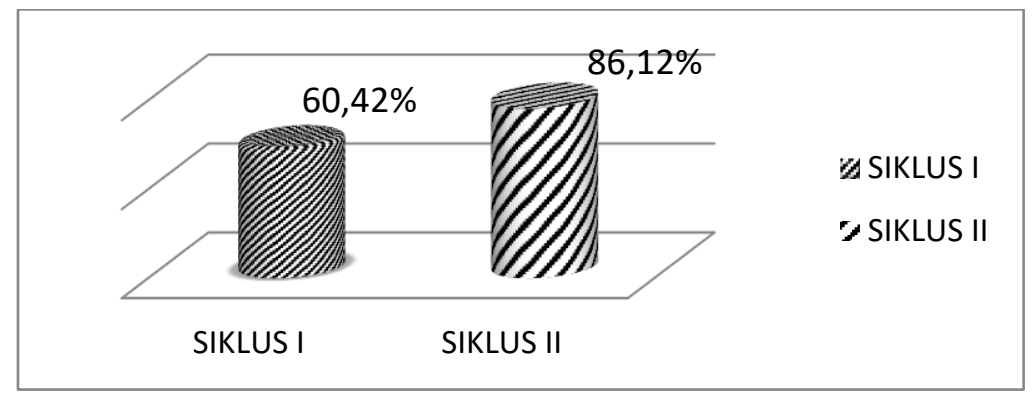

Gambar 1.2 peningkatan persentase motivasi belajar siswa siklus I dan siklus II

Siklus I menunjukkan persentase motivasi siswa secara umum sebesar $69,46 \%$, untuk siklus I lebih kecil dari siklus II, ini disebabkan peserta didik kurang memperhatikan guru saat pembelajaran, siswa tidak menggunakan seluruh waktu untuk belajar, tidak mengerjakan tugas yang diberikan oleh guru, siswa tidak menjawab pertanyaan dari guru. sedangkan pada siklus II mengalami peningkatan mencapai 91,3\%, hal ini dikarenakan siswa memperhatikan guru pada saat mengajar, siswa menggunakan selauruh waktu untuk belajar dan berdiskusi, siswa aktif menjawab pertanyaan dari guru,siswa aktif bertanya jika belum paham mengenai materi yang telah dibahas.

Peningkatan motivasi belajar siswa di karenakan penelrapan model Creative Problem Solving mengajak siswa untuk aktif dalam kegiatan pembelajaran yang dapat memacu siswa untuk mengevaluasi pemahamannya dan mengidentifikasi kesalahan dalam berpikirnya, sehingga siswa mampu mengembangkan daya nalarnya secara kritis untuk memecahkan masalah yang dihadapi. Penerapan model pembelajaran CPS dapat melatih siswa dalam menyelesaikan soal-soal yang baru yang lebih bervariasi dan solusi yang bermacam-macam yang lebih beragam dan kemampuan berpikir kreatif siswa dalam proses pembelajaran dapat dilihat dari munculnya pertanyaan, menggali informasi yang ada dan cendrung memiliki hasrat ingin tahu dan ini merupakan motivasi yang dimiliki siswa pada saat pembelajaran apabila masalah yang disajikan berkaitan dengan kehidupan sehari-hari (Kuswanto, 2016).

Minat meliputi menunjukan sikap ingin tahu dengan mengajukan pertanyaan kepada pendidik, siswa aktif dalam praktikum, siswa mengemukaan ide dengan mengambungkan peristiwa yang pernah dilakukan dengan pelajaran yang dipelajari, peserta didik berusaha mencari jawaban dari pertanyaan peserta didik dengan cara membaca buku. Pada siklus I minat peserta didik masih rendah hal ini dikarenakan siswa tidak menunjukan sikap ingin tahu, siswa kurang aktif dalam melakukan praktikum, siswa kurang mengaitkan materi yang dipelajari dengan peristiwa yang pernah dilakukan, siswa tidak membaca buku sehingga siswa tidak bisa menjawab pertanyaan guru. sedangkan pada siklus II minat siswa meningkat, hal ini karena siswa sering mengajukan pertanyaan kepada guru, siswa berusaha mencari jawaban dengan membaca buku dan siswa aktif dalam melakukan praktikum. Persentase keterlaksanaan aspek minat pada siklus I sebesar 56,3\%, sedangkan pada siklus II $84,7 \%$, sehingga dapat dilihat bahwa aspek minat mengalami peningkatan.

Minat belajar yang ditunjukan melalui siswa mengikuti pelajaran sampai akhir, siswa aktif dalam pembelajaran dan terlibat aktif dalam keseluruhan kegitatan pembelajaran. Ini berdasarkan minat siswa pada siklus I dan pada siklus II, pada siklus I minat siswa masih kurang sehingga ada perbaikan. Perbaikan ini menyebabkan adanya peningkatan pada siklus II. Perbaikan tersebut sangat efektif meningkatkan motivasi belajar terutama pada aspek minat. Upaya untuk meningkatkan mutu pendidikan dan minat siswa adalah dengan cara membuat inovasi-inovasi baru dan model pembelajaran baru. Inovasi-inovasi pemeblajaran baru nerkaitan dengan menciptakan suasana dan proses pemeblajaran yang kondusif bagi siswa sehingga siswa berminat mengikuti pemeblajaran (Ginanjar, 2015).

Perhatian meliputi memperhatikan kelompok pada saat mempresentasikan hasil diskusi didepan kelas mengikuti setiap instruksi yang diberikan oleh guru, memusatkan perhatian pada materi, tugas yang diberikan guru tidak dikerjakan. Pada siklusi I siswa tidak memperhatika siswa yang mempresentasi hasil diskusi, tidak memperhatikan materi yang dijelaskan guru. 
sedangkan pada siklus II guru lebih menekanakan peserta didik agar mencermati materi yang dijelaskan pendidik serta memberi sanki apa bila ada peserta diidik yang tidak memperhatikan guru .Persentase keterlaksanaan aspek perhatian untuk siklus 1 mencapai 66,3\% dan untuk pada siklusi II $85,6 \%$, sehingga dapat disimpulkan bahwa adanya peningkatan keterlaksanaan aspek perhatian. Untuk membuat siswa termotivasi dan memusatkan perhatian rasa ingin tahu meraka harus terangsang dan berkelanjutan, dan merka harus memiliki keyakinan bahwa mereka akan sanggup untuk berhasil dalam proses pembelajaran dan berkonsekuensi dri pengalaman belajar harus konsisten dengan pribadi insentif dari peserta didik (sadirman, 2006)

Konsentarsi meliputi kehadiran siswa dikelas penuh sampai pelajaran berakhir, siswa menggunakan seluruh waktu pelajaran untuk belajaran, mendengarkan dan memperhatikan saat guru memberikan petunjuk LKS maupun menjelaskan materi yang tekait, memusatkan perhatian pada saat temannya melakukan presentasi. Pada siklus I peserta didik kurang menggunakan waktu untuk belajar tetapi siswa ada yang bercanda dan tidak konsentrasi saat pembelajaran. Sedangkan pada siklus II mengalami peningkatan hal ini dikarenakan guru meminta siswa untuk konsentasi dalam pemeblajaran dan menegur siswa yang tidak memperhatikan penjelasan guru. presentasi pada siklus I 58,8\% dan pada siklus II sebesar $85,6 \%$, hal ini karena ada perbaikan pada siklus I sehingga dapat disimpulkan bahwa adanya peningkatan pada pelaksanaan sisklus II.

Dari perbaikan tersebut siswa lebih memperhatian apa yang disampaikan oleh guru, siswa tidak keluar masik kelas, siswa tidak menganggu teman yang presentasi. Sehingga siswa memahami pelajaran yang dijelaskan Untuk membuat siswa termotivasi dan memusatkan konsentrasi rasa ingintahu meraka harus terangsang dan berkelanjutan, dan meraka harus memiliki keyakinan bahwa mereka akan sanggup untuk berhasil dalam proses pembelajaran. Konsentrsi siswa pada reaksi siswa terhadap stimulus yang diberikan oleh guru ketika guru bertanya kepada siswa dan siswa menjawab pertanyan dan bertanya kembali kepada guru jika belum mengerti (Slameto, 2010)

Pemahaman materi meliputi menjawab pertanyaan yang diajukan guru, dapat menyelesaikan LKS dengan benar, terlibat aktif peneuh dalam membahas materi-materi yang dipelajari dan melakukan percobaan dengan benar. Pada siklus I masih rendah hal ini dikarenakan siswa kurang aktif dalam menjawab pertanyaan guru terkadang siswa sibuk sendiri saat guru memberi pertanyaan kepada siswa. Sedangkan pada siklus II mengalami peningkatan hal ini dikarenakan guru sering memberikan contoh soal sehingga sisw memahami, dan guru menjelaskan materi secara terperinci sehingga siswa dapat memahami meskipun secara berlahan. Persentase keterlaksanaan pemahaman materi pada siklus I sebesar $60 \%$ dan siklus II $88,5 \%$, hal ini dapat disimpukan bahwa adanya peningkatan pada pelaksanaan pemahaman materi .

Dari perbaikan tersebut siswa lebih memperhatian apa yang disampaikan oleh guru. Untuk membuat siswa memahami materi harus ada interaksi antara guru dan siswa dengan demikian guru dapat mengatahui kemampuan pemahaman dari setiap siswa. guru lebih pelan menjelaskan materi supaya siswa dapat memahaminya. Interaksi antara guru dan siswa dan interaksi antara sisw dalam kelas sangat berpengaruh besar terhadap pemahaman siswa terhadap materi (Mujito, 2013)

Tekun meliputi menyelesaikan tugas tepat waktu, saling memberikan masukan untuk setiap pertanyaan, aktif dalam bekerja sama didalam kelompok, catatat pelajaran lengkap dan rapi. Pada siklus I masih rendah hal ini dikarenkan masih ada siswa yang tidak mengerjakan tugas, siswa kurang kerja sama dalam kelompok,masig ada siswa yang duduk dikelompok temanya dan menganggu teman kelompok lain, masih ada siswa yang catatan tidak lengkap. Sedangkan pada siklus II mengalami peningkatan hal ini karena guru memberikan motivasi untuk siswa supaya mengerjan tugas tepat waktu dan memberikan pertanyaan jika belum paham dengan materi. Persentase keterlaksaan aspek tekun pada siklus I 60,7\% dan pada siklus II $86,3 \%$, sehingga dapat disimpukan bahwa adapeningkatan pada keterlasaanaaan aspek tekun.

Pada saat pembelajaran berlangsung siswa tidak menyelesaikan tugas secara keseluruhan tidak aktif dalam berdiskusi, ada siswa yang diskusi tetapi bukan tentang materi yang dipelajari, sehingga membuatan keributan dalam kelas. Guru mengontrol siswa dalam menyelesaikan tugasnya. Siswa akan terpacu untuk menyelesaikan tugas jika dibimbing oleh 
guru.perbaikan ini meningkat motivasi belajar terutama aspek tekun. Perhatian adalah salah satu pont penting dalam meningkatkan motivasi belajar peserta didik.Tekun ialah tindakan yang sangat penting untuk meningkatkan hasil belajar peserta didik agar lebih baik (Aritonang, 2008)

\section{PENUTUP}

Berdasarkan paparan data dan temuan penelitian yang diperoleh dari hasil penelitianmaka kesimpulan yang dapat diambil adalah sebagai beriku, Kualitas keterlaksanaan model pembelajaran Creative Problem Solving yang dilakukan di kelas VIII-A SMP PGRI 6 Malang memperoleh skor tertinggi 91,7\% dan kategori sangat baik, Penerapan Model Creative Problem Solving dapat meningkatkan motivasi belajar siswa pada mata pelajaran IPA kelas VIII-A SMP PGRI 6 Malang. Hal ini terlihat pada kualifikasi pada siklus I kualifikasi baik. Secara keseluruhan motivasi belajar pada siklus I dan siklus II dari cukup baik menjadi baik, dan Penerapan model Creative Problem Solving dapat meningkatkan litersai sains siswa pada mata pelajaran IPA. Secara keseluruhan literasi sains siswa pada siklus I dan siklus II yaitu kualifikasi baik.

\section{DAFTAR PUSTAKA}

Aini, Q. (2016). pengaruh motivasi belajar intrinsik dan ekstrinsik terhadap prestasi belajar. di SMA NW Pancor Lombok Timur NTB: STKIP Hamzanwadi:Bima. Diakses tanggal 9 pebuari 2018.

Arikunto, S. 2010. Prosedur Penelitian Suatu Pendekatan Praktik. Jakarta: PT Rineka Cipta

Arikunto. (2006). prosedur penelitian suatu pendekatan praktis, Ed Revisi VI. jakarta: PT Rineka Cipta.

Aritonang, k. T. (2008). Minat dan motivasi dalam meningkatkan hasil belajar siswa. jakarta.

Ginanjar. (2015). penerapan model problem based learning untuk meningkatkan minat dan prestasi belajar siswa Kelas XI SMAN 7 Surabaya.

Hartati \& Asyari, A. (2015). profil peningkatan kemampuan literasi sains siswa melalui pembelajaran saintifik. Retrieved 28, 2018.

Hamzah, d. (2011). penerapan metode Creative problem solving untuk meningkatakn aktifitas siwa. sukarta: Universitas Muhammadiyah sukarta.

Huda, M. (2014). Model-model pengajaran dan pembelajaran. yogyakarta: pustaka pelajar.

Kemendikbud. 2016. Penguatan Literasi Dalam Pembelajaran. Jakarta: Kementrian Pendidikan dan Kebudayaan

Kemendikbud. 2017. Materi Pendukung Literasi Sains. Jakarta: Kementrian Pendidikan dan Kebudayaan.

Kuswanto, H. (2016). Pengembangan kemampuan berpikir kreatif matematis siswa melalui model pembelajaran Creative Prblem solving.

Kriswahyudi, D. (2009). Definisi Daya serap. diambil dari http://library.um.ac.id pada tanggal 3 mei 2016.

Majid, A. (2013). Startegi Pembelajaran . Bandung: PT Remaja Rosdakarya.

Mudjiono \& Damyati. 2006. Belajar dan Pembelajaran. Penerbit Rinika Cipta:Jakarta

Muslich, M. (2007). pembelajaran Berbasis Kompetensi. jakarta: Bumi Askara.Nihayah, Rizqi P. (2013). Peningkatan Motivasi Belajar dan Hasil Belajar Menghias Busana dengan Model pembelajaran Langsung Berbantuan Media Wallchart di SMKN1 Pengasih Kulonprogo. Yogyakarta: Tidak Dipublikasikan

Rusilowati, A. 2013. Peningkatan Literasi Sains Siswa Melalui Pengembangan Instrumen Penilaian. Pidato Pengukuhan Profesor Unnes Semarang.

Rustini, T. (2008). Penerapan Model Problem Solving Untuk Meningkatkan Pengembangan Potensi Berpikir Siswa Dalam Pembelajaran IPS Di Sekolah Dasar. Jurnal Pendidikan Dasar, Nomor: 10.

Rustaman, d. (2011). Membangun Literasi Sains peserta didik. Bandung: Humaniora.

Sardiman,A.M. 2001. Interaksi dan Motivasi Belajar Mengajar. Jakarta:Grafindo. 
Sardirman, A.M. 2005. Interaksi dan Motivasi Belajar Mengajar. Jakarta:Grafindo.

Sujarwo. (2012). Model-model pembelajaran suatu srategi mengajar. yogyakarta

Rustini, T. (2008). Penerapan Model Problem Solving Untuk Meningkatkan Pengembangan Potensi Berpikir Siswa Dalam Pembelajaran IPS Di Sekolah Dasar. Jurnal Pendidikan Dasar, Nomor: 10. 